http://dx.doi.org/10.11646/phytotaxa.163.5.5

\title{
Agave dealbata E.Morren ex K.Koch (Asparagaceae), the correct name for Agave dasylirioides Jacobi \& C.D.Bouché (Nomenclature of Agave L. I)
}

\author{
JOACHIM THIEDE \\ Schenefelder Holt 3, 22589 Hamburg, Germany; email: joachim_thiede@gmx.de
}

The genus Agave Linné (1753: 323; Asparagaceae-Agavoideae) has played an important role for the indigenous civilizations of North America ("man-Agave symbiosis") and is of considerable economical and horticultural importance (Gentry 1982). Many new Agave species were introduced between about 1860 and 1890 particularly from Mexico. Frequently, new taxa have a complicated nomenclatural history with often multiple introductions or descriptions by different, partly competing authors and in publications often difficult to access (e.g., Govaerts $\&$ Thiede 2013). This has led to a considerable number of incorrect author citations and/or places of publication in taxonomic treatments as well as databases such as IPNI (2013). In the framework of a second, updated edition of a taxonomic synopsis of Agave (Thiede, in prep.), at least some uncertain and controversial nomenclatural issues will need to be addressed, starting here with $A$. dealbata.

Agave dealbata is commonly ascribed to Lemaire ex Jacobi in Hamburger Garten- Blumenzeitung 21: 346 , Aug. 1865 (Jacobi 1865: 346). Recent treatments (e.g., Gentry 1982, Thiede 2001, IPNI 2013, Govaerts et al. 2013) place $A$. dealbata in the synonymy of $A$. dasylirioides Jacobi \& C.D.Bouché which was published by Jacobi (1865: 344) in the same paper two pages before $A$. dealbata. Jacobi (1865: 346) ascribed $A$. dealbata to Lemaire ex Jacobi ("A. dealbata. Lem.", latin diagnosis endorsed with "Nob.") and mentioned that he found the plant first in summer 1863 at Gand (Belgium) exhibited by the Belgian nurseryman L. de Smet. However, the name $A$. dealbata was first mentioned by E.Morren (1859: 204) for a specimen exhibited by de Smet, and no mentioning in printed matter by Lemaire (e.g., in Ill. Hort.) was found.

Through my research, it came to my attention that a valid description of $A$. dealbata was provided three years before Jacobi by K.Koch in Wochenschr. Vereines Beförd. Gartenbaues Königl. Preuss. Staaten. 5(No. 24): 192, 14. Jun. 1862 (Koch 1862a), based on a living specimen which Koch saw in the greenhouse of the Belgian Senator Cannart d'Hamale at Mechelen (Belgium): “eine Agave ... wunderschönen blaugrünen Farbe ... hatte den Namen A. dealbata und besass ein eigenthümliches Ansehen. Im Wuchse glich sie mehr einem Dasylirion, so dicht und gedrängt standen die flachen und ziemlich steifen Blätter von 16 Zoll Länge und 6 bis 8 Linien Breite". Four month later in the same year, Koch (1862b: 341) published additional data on his A. dealbata, and three years later, he provided a more detailed description (Koch 1865: 110), adding that the leaf color ranges from blue to grey or dull green and that Jacobi published a specimen with dark green leaves which flowered at BG Berlin as A. dasylirioides. Six years later, Koch (1871) noted that the same specimen may switch its name between $A$. dealbata and $A$. dasylirioides, that even the plant at Berlin on which Jacobi based his description of $A$. dasylirioides was later named $A$. dealbata, and that $A$. dealbata was not first named by Lemaire as stated by Jacobi but by himself in Wochenschr. ... 5: 192, 1862, as cited above. Consequently, A. dealbata antedates A. dasylirioides, and the synonymy is as follows:

Agave dealbata E.Morren ex K.Koch, Wochenschr. Vereines Beförd. Gartenbaues Königl. Preuss. Staaten 5(No. 24): 192, 14. Jun. 1862 三 Agave dealbata E.Morren, Belgique Hort. 9: 204. 1859, nomen. - Type: cultivated plant seen by Koch in the greenhouse of the Belgian Senator Cannart d'Hamale at Mechelen, Belgium (not known to be preserved). - Neotype (designated here): Mexico, Tuffaceous cliffs by Tepoztlan, Morelos, alt. 5500-6500 feet. December 1, 1967. H.S.Gentry [\& Tejeda] 22498 (DES 30824!). Isoneotypes: ASU!, MEXU, US (according to Gentry 1982: 249); digital images accessed via SEINet 2013.

= Agave dealbata Lemaire ex Jacobi, Hamburger Garten- Blumenzeitung 21: 346, Aug. 1865. nom. illeg. (ICN Art. 53.1) $\equiv$ Agave dasylirioides var. dealbata (Lemaire ex Jacobi) A.Terracciano, Prim. Contr. Monogr. Agave: 15, 1885. syn. nov. - 
preserved in March 1863. In order to validly designate a type specimen, the most complete specimen (sheet \#1) is designated here as neotype.

Typification of Agave intrepida. In his protologue, Greenman (1899) cites C.G.Pringle 6868 as type collection, but no holotype. Consequently, all specimens of that collection comprise original material (ICN Art. 9.3; McNeill et al. 2012). Here, the specimen kept in the country of origin at MEXU is designated as lectotype; all other specimens represent isolectotypes.

Nomenclature: To serve the stability of nomenclature (ICN Art. 14.2, McNeill et al. 2012), a proposal to conserve the established, but younger $A$. dasylirioides Jacobi \& C.D.Bouché (1865) over the older $A$. dealbata E.Morren ex K.Koch (1862) is in preparation by the author.

Distribution: The type plant of $A$. dasylirioides Jacobi \& C.D.Bouché cultivated at BG Berlin was indicated to have been collected by Warszewicz in Quezaltenango ("Quessoltinango") in Guatemala (Jacobi 1865: 344). Hooker (1868) gives a Mexican origin for plants flowering at Kew. Berger (1915:83) recognizes $A$. dasylirioides and $A$. dealbata as separate species differing in leaf size. For the former, Berger repeats the Guatemalan origin, but for the latter, he provides the first documented localities in citing the collections Pringle 6868 from 1898 (the type of $A$. intrepida Greenman 1899 which he refers to the synonymy) and Pringle 8095 from 1899, both collected in the Mexican state of Morelos. Gentry (1982: 249) placed $A$. dealbata as well as $A$. intrepida in the synonymy of $A$. dasylirioides, rejected the purported origin from Guatemala as doubtful and cited three collections of Pringle and three own ones from Morelos as well as one collection from San Luis Potosí (Rzedowski 7128a). The latter most probably belongs to the recently published A. gracielae Galván \& Zamudio (2013). A specimen collected in the state of Mexico (Castañeda Rojas 72 et al., MEXU, digital image! accessed via SEINet 2013) extends the known range of the species.

Ullrich (1990) reported sterile plants named A. dasylirioides from near Yosondua in the state of Oaxaca, ca. $270 \mathrm{~km}$ south of Morelos, which were first collected there by A. B. Lau in 1988. Polka (2006) showed flowering plants in habitat near Yosondua as Agave dasylirioides, but these differ clearly from that species in having reddishpurple flowers. Recently, the plants from near Yosondua were published as a new species Agave kavandivi GarcíaMendoza \& Chávez-Rendón (2013) which differs from A. dasylirioides esp. in its branched habit (vs. solitary in the latter), and its reddish inflorescences with purple flowers.

\section{Acknowledgements}

The author is indebted to two anonymous reviewers for their comments, to N. Turland (B) for information on and photographs of specimens at B, and to M. Greulich (Berlin) for literature and additional information.

\section{References}

Anonymous (1889) Agave dasylirioides. Gardeners' Chronicle Ser. 3, 5: 804-805.

Berger, A. (1915) Die Agaven. Beiträge zu einer Monographie. G. Fischer, Stuttgart, 288 pp. http://dx.doi.org/10.5962/bhl.title.15643

Galván, R. \& Zamudio, S. (2013) Une nueva especie de Agave subgénero Littaea (Agavaceae) de la Sierra Madre Oriental, México. Acta Botanica Mexicana 105(4): 1-10.

García-Mendoza, A.J. \& Chávez-Rendón, C. (2013) Agave kavandivi (Agavaceae: grupo Striatae), una especie nueva de Oaxaca, México. Revista Mexicana de Biodiversidad 84: 1070-1076. http://dx.doi.org/10.7550/rmb.35241

Gentry, H.S. (1982) Agaves of Continental North America. University of Arizona Press, Tucson, 670 pp.

Govaerts, R. \& Thiede, J. (2013) Transfer of Polianthes geminiflora into Agave (Asparagaceae): new combinations (Nomenclature of Agave II). Willdenowia 43(4): 331-333. http://dx.doi.org/10.3372/wi.43.43215

Govaerts, R., Zonneveld, B.J.M. \& Zona, S.A. (2013) World Checklist of Asparagaceae. Facilitated by the Royal Botanic Gardens, Kew. Available from: http://apps.kew.org/wcsp/ (accessed 13 May 2013).

Greenman, J.M. (1899) Some new species, extended ranges, and newly noted identities among the Mexican phanerogams. Proceedings of the American Academy of Arts and Sciences 34: 566-578.

http://dx.doi.org/10.2307/20020931 
Hooker, J.D. (1868): Agave dasylirioides. Curtis's Botanical Magazine 94 [ser. 3, 24]: tab. 5716.

International Plant Names Index (IPNI) (2013). Available from: http://www.ipni.org (accessed 13 May 2013).

Jacobi, G.A. von (1865[Aug.]) Versuch zu einer systematischen Ordnung der Agaveen (IX). Hamburger Garten- und Blumenzeitung 21: 341-346.

JSTOR Global Plants (2013). Available from: http://plants.jstor.org/ (accessed 3 Dec 2013).

Koch, C. (1862a[14.Jun.]) Ein Ausflug nach Belgien und nach den Niederlanden im ersten Frühjahre 1862. Wochenschrift des Vereines zur Beförderung des Gartenbaues in den Königlich Preussischen Staaten 5(No. 24): 188-192.

Koch, C. (1862b[25.Oct.]) Der Internationale Kongress für Pomologie und die Pflanzen-, Blumen-, Obst- und GemüseAusstellung in Namur. Wochenschr. ... 5(No.43): 337-343.

Koch, C. (1865[8.Apr.]) Agaveen-Studien (IV). Wochenschr. ... 8(No. 14): 108-112.

Koch, C. (1869[10.Apr.]) Mitteilungen über die neuesten Pflanzen. Wochenschr. ... 12(No. 14): 105-108.

Koch, C. (1871[2.Sep.]) Footnote to: de Jonge van Ellemeet: Eine Agaven-Sammlung. Wochenschr. ... 14(No. 35): 276-277, 2.Sep. 1871 .

Linné, C. v. (1753) Species plantarum t. 1. Laurentii Salvii, Holmiae, 560 pp.

McNeill, J., Barrie, F.R., Buck, W.R., Demoulin, V., Greuter, W., Hawksworth, D.L., Herendeen, P.S., Knapp, S., Marhold, K., Prado, J., Prud'homme van Reine, W.F., Smith, G.F., Wiersema, J.H. \& Turland, N.J. (ed.) 2012: International Code of Nomenclature for algae, fungi, and plants (Melbourne Code) adopted by the Eighteenth International Botanical Congress Melbourne, Australia, July 2011. Koeltz Scientific Books, Königstein, 240 pp. [Regnum Veg. 154].

Morren, E. (1859) Les expositions du printemps de 1859, en Belgique. Belgique Horticole 9: 193-204.

Polka, W. (2006) Agave dasylirioides Jacobi \& Bouché. Berliner Kakteenblätter 6: 25-26.

Röpert, D. (ed.) (2013): Digital specimen images at the Herbarium Berolinense. Available from: http://ww2.bgbm.org/ herbarium/default.cfm (accessed 3 Dec 2013).

SEINet Southwest Envirionmental Information Network (2013). Available from: http://swbiodiversity.org/seinet/index.php (accessed: 3 Dec 2013).

Terracciano, A. (1885) Primo Contributo ad una Monografia delle Agave. Barnaba Cons di Antonio, Napoli, 58 pp.

Thiede, J. (2001) Agavaceae. In: Eggli, U. (ed.) Illustrated Handbook of Succulent Plants. Monocotyledons. Springer, Heidelberg, pp. 5-102.

Ullrich, B. (1990) Ein neuer Standort für A. dasylirioides Jacobi \& Bouché in Oaxaca. Kakteen und andere Sukkulenten 41(8): $164-166$. 